This is an electronic reprint of the original article. This reprint may differ from the original in pagination and typographic detail.

Author(s): Elmgren, Heidi

Title: Recognition and the Ideology of Merit

Year: $\quad 2015$

Version:

Please cite the original version:

Elmgren, H. (2015). Recognition and the Ideology of Merit. Studies in Social and

Political Thought, 25, 152-173. https://doi.org/10.20919/sspt.25.2015.32

All material supplied via JYX is protected by copyright and other intellectual property rights, and duplication or sale of all or part of any of the repository collections is not permitted, except that material may be duplicated by you for your research use or educational purposes in electronic or print form. You must obtain permission for any other use. Electronic or print copies may not be offered, whether for sale or otherwise to anyone who is not an authorised user. 


\section{Recognition and the Ideology of Merit ${ }^{1}$}

\section{by Heidi Elmgren}

\section{Introduction}

In this paper I will examine French philosopher Dominique Girardot's ${ }^{2}$ theory of the ideology of merit and its effect on recognition. Girardot takes the well-known Honnethian conceptualization of recognition as her starting point but her work opens a path toward other directions: understanding the reasons for lack of recognition in society, and how the nature of recognition as a freely issued gift is at stake. Girardot's theory of recognition also enables the possibility of recognizing something completely new that transforms norms rather than simply conforming to pre-existing standards. This is made possible by the influence of Hannah Arendt's theoretical framework of human activity on Girardot's conception of recognition.

I will first take a look at Girardot's theory of the ideology of merit and then go on to examine briefly how Girardot's conception of recognition differs from that of Axel Honneth. After this I will give an account of the relation between the ideology of merit and Girardot's conception of recognition. In the second part of the paper I will outline how the ideology of merit creates, according to Girardot, a new kind of social pathology. I wish to argue that the pathology in question is a pathology of recognition. In Hannah Arendt's terminology, the ideology of merit seeks to force all human activity to fit the category of labor and consequently denies the category of action, the most human and political category of activity. For Girardot, the single most disturbing consequence of our misled conception of merit is the search for objectified recognition. This means that the essence of recognition is forgotten and replaced by a distorted, standardized and meaningless version of it. The standardization of recognition by identifying it with objectified merit creates a pathology of recognition: attaining recognition in the public sphere becomes very difficult.

\section{Recognition Meets the Ideology of Merit}

\subsection{The Arendtian Background: Action, Plurality, and Judgment}

To understand Girardot's theory of recognition one must first take notice of 
Girardot's conceptual and theoretical background in Hannah Arendt's theory of human activity. Arendt divides human activity into three categories: labor, work and action. Labor refers to the production of things 'needed for the life process itself' (Arendt 1998, 96). Philosopher Sara Heinämaa lists nutrition, clothing, and cleaning as examples of labor activities. Labor's products are not meant to serve any other ends than the continuation of the process of life and laboring itself (Heinämaa, forthcoming). Work creates the human world through the production of relatively durable and permanent things such as buildings, furniture, clothes, and pieces of music. The products of work do not spoil and disappear from the world as, for instance, food does if it is not consumed relatively quickly (Arendt 1998, 138). The category of action is the most 'human' of the types of activities. In comparison to labor and work, action does not produce anything concrete. 'Action and speech,' as Arendt puts it $(1998,95)$, 'together constitute the fabric of human relationships and affairs.' Speech and action do not bring forth things as such, but through them human beings show who they are. Through action their 'unique distinctness'(Arendt 1998, 176) manifests itself.

Heinämaa also points out, following Arendt that non-laboring activities - that is, activities categorized as action and work-can be 'encompassed' as laboring. This happens when these activities are subordinated to the needs and necessities of biological life (Heinämaa, forthcoming). This is a crucial point for Girardot as well. According to Girardot, the ideology of merit tries to force all of human life to fit the category of labor and at the same time operates to deny the category of action. The ideology claims that the meaning of action could be reduced to what can be measured. So, when critiquing merit measuring procedures, Girardot is critiquing the attempt to measure what Arendt calls action (Girardot 2011, 119-129).

Two other important Arendtian concepts in Girardot's theory are plurality and natality. Human life, according to both Arendt and Girardot, is manifested in a plurality of unique beings. Human beings are not identical but unique, and yet they are equal. If they were not equal they could not understand each other at all. But were they identical there would be no need for speech: simple signs and gestures would be enough to help human beings understand each other's identical needs (Arendt 1998, 175-176). Plurality stems from another condition of human life, that of natality: the 'second birth' that a child undergoes as she or he learns to speak. Natality is for Arendt the introduction of something unforeseen among human beings. As the child enters the speech community she or he becomes capable of action, which Arendt characterizes as 'the capacity of beginning something 
anew' (Arendt 1998, 9). Natality, plurality and action are all closely woven together: natality serves as the basis for plurality and through action human beings distinguish themselves rather than merely remaining distinct. It is our uniqueness, rooted in natality, that makes beginning something new and unforeseen possible: in short, makes action possible.

Finally, a few words on judgment. Judgment for Arendt is a faculty of the mind: it is the 'ability to tell right from wrong, beautiful from ugly' (Arendt 1971, cited in Benhabib 1988, 30). For Arendt, judgments 'are not arrived at by either deduction or induction' (Arendt 1992, 4), for judgment deals with particulars, not universals. Judgment is then not a logical operation - which of course does not mean irrational. Arendt's untimely death meant she could never fully systematize her thoughts on judgment. In Girardot's treatment judgment is taken to be the human capacity to assess complex situations without resorting to mechanistic, pseudo-objective measuring or calculation. For this kind of mechanistic assessment, which is the target of her critique, she has reserved the term 'evaluation' (See e.g. Girardot 2011, 117).

\subsection{Merit and the Ideology of Merit}

The term 'merit' refers to skills, abilities and personal traits that are valued in a certain community of value. In everyday life merits are understood as positive criteria that determine who will be, for instance, hired or allowed access to a certain education. Merit stands out as the opposite of privilege, and as such it is a fitting concept of value for a democratic society. Merit represents the refusal of injustices and the ideal that all human beings are born equal (Girardot 2011, 38).

In her book La Société du mérite - Idéologie méritocratique E violence néolibérale (2011) Girardot analyses the contemporary understanding of merit and what she sees as problematic about it. According to Girardot, merit is the criterion of distinction that democratic societies need and should apply. But despite its links to the idea of justice, Girardot argues, the criterion's application scope has expanded wildly, and merit is now seen as a pertinent criterion even in situations and places into which it should never have entered (Girardot 2011, 45).

Many scholars have written about the so-called 'myth of meritocracy' or 'meritocracy myth' (see e.g. Jenkins 2013, MacNamee 2009). These synonymous concepts refer to a rather widely shared (false) belief that our systems of hiring, education and so on already fulfil the meritocratic ideals. By contrast, it seems that meritocratic and supposedly fair procedures (used 
in hiring, for instance) produce biased outcomes: for instance that the ones being hired are more likely young men than older women. However, the myth of meritocracy leads us to think that those who claim that the procedures are biased simply are not willing to accept the personal failures of those rejected or excluded. Due to this myth, many forms of discrimination such as outright sexism, racism and ageism are taken to be matters of history; the meritocratic procedures are supposed to prove that younger and/or white men are better than, for instance, older black women at mentally or physically demanding tasks and professions. I argue that for Dominique Girardot, the myth of meritocracy is part of the functioning of what she calls the ideology of merit. Her overall theory shows that our current understandings of merit and meritocracy are more deeply problematic than the 'myth of meritocracy' conceptualization allows to be examined.

Girardot argues that the concept of merit has become a self-evident part of our conceptual framework. It is starting to dictate how we conceptualize the social-cultural world and relations (Girardot 2011, 37). In Girardot's account, merit is gradually turning into an explanatory tool that supposedly explains why some people are doing well and some are sick, poor, and/or stupid. So rather than functioning solely as a criterion for measuring and evaluating in social situations, merit is used in an everincreasing number of cases to explain and justify the current state of affairs. Merit is the way to explain why some people are successful in acquiring resources, opportunities and services: they have acquired merits. But merit is also used to explain the opposite phenomenon: those still struggling for resources and opportunities are said not to have enough merits (Girardot 2011, 42-44).

For Girardot, merit can stand as the criterion for distinction and legitimize someone's social standing. However, our current conception of merit supposes that merit determines the value of people's actions in any situation; that people's relations to each other and to themselves should be structured by merit. Factors that might affect a person's abilities are evoked only to further explain the lack of merit of the person in question: sickness, loneliness and failure are all coded as indicators of a lack of merit (Girardot $2011,42)$. Due to the concept's expansion from its sphere of pertinence, Girardot argues, our conception of merit has turned ideological.

Girardot's account of ideology follows that of Hannah Arendt. For Arendt, ideology is 'quite literally what its name indicates: the logic of an idea,' where 'the "idea" of an ideology ... has become an instrument of explanation' (Girardot 2011, 39; Arendt 1986, 469). Girardot claims that merit is assuming the role of an all-encompassing ideology in our conceptual 
system (Girardot, 2011 39-40).

Any ideology tends to eliminate competing views of the world and any positions that conflict with its dogma to maintain itself as the main explanatory tool. Since logic, as Arendt puts it, is 'the process of deduction from a premise' (Arendt 1986, 469) the only things that can be allowed to exist, to be considered as 'real', are the things that can be deduced from the premise. What cannot be deduced from the idea cannot be. Thus, following Girardot, ideology 'tears reality' to make it fit its own idea of the world. Our conception of merit has distorted our conception of reality and replaces the complexity of life with the simplicity of an idea (Girardot 2011,39). The conception of merit has become totalizing: all the complexities and unforeseeable consequences of actions that make up life are cast aside and replaced by simplistic reasoning, a totalizing logic of an idea. Merit has become an instrument of explanation and what it seeks to explain is social inequality and individual success and failure. The ideology of merit turns any situation into a question of someone's individual responsibility and (lack of) merit. ${ }^{3}$ In this way the ideology of merit seemingly justifies situations that we might otherwise analyse and criticize as social wrongs.

The ideology of merit seeks to explain and justify why, for instance, a sick person should be the only one responsible for their hospital bills: it can be seen that they had something to do with the origin of illness (did they exercise enough? Did they have the influenza vaccination? and so on) and so it is inferred, according to the logic of the idea, that no one else owes this person care or help, financial or otherwise: they in a way deserve their illness for there were precautions they could have taken to avoid it but chose not to. ${ }^{4}$ The ideology of merit links the problems of a wrong scope of consideration and biased consideration. It does not seem reasonable to ask whether someone 'deserves' to be sick or not: even if the person did bring the illness upon themselves, they did not 'deserve' it, they merely caused it. However, the ideology of merit with its all-encompassing force brings this question of desert to the situation. His situation may be worsened if he happens to be a member of an underappreciated class of people in the area where he seeks healthcare. He may be thought to deserve the illness even more than a member of the dominant class. The ideology of merit claims that merit is the best criterion with which to evaluate what each person deserves. It is capable of bringing this question of desert, of being merited, into all situations where something is being shared. This means that the problems related to bias that used to be somewhat limited can now be found in new and even more problematic situations. The ideological concept of merit makes the biases appear natural and unavoidable: additional proof of the lesser abilities, lack of innate talent and tendency to make poor life choices 
of marginalized groups.

\subsection{Girardot, Arendt and Honneth}

German philosopher Axel Honneth distinguishes three forms of recognition: emotional support (in primary relationships that feature love and friendship), cognitive respect (in legal relations; cognitive respect is shown by guaranteeing legal rights) and social esteem (recognition of personal traits and abilities by the community of value; Honneth 1995, 92-130). It is this third type of recognition in which merits may be invoked: we may esteem a person for their merits; that is, grant esteem to persons who are able to do things that require skill and training such as speak several foreign languages fluently, type very quickly, take good care of children, write inspiring poems, and so on.

Girardot refers to Honneth as a starting point for the questions concerning recognition (Girardot 2011, 32 fn. 1, 140) and points out that the ideology of merit causes 'in Honnethian terms' a social pathology (ibid, 143). However, Girardot makes a distinction between two kinds of recognition instead of three: respect (which is for everyone because of their uniqueness) and admiration (recognition for remarkable deeds and people; Girardot 2011, 188). Most frequently, Girardot simply writes 'recognition' and the reader must infer from the context whether this refers to respect or admiration or both. The aim of Girardot's discussion on recognition is to take notice of the sentiments of injustice which increase despite the efforts to guarantee fairness of treatment by measuring merit as exactly as possible (Girardot 2011, 28): to point out a qualitative difference between standardized recognition and a more authentic type of recognition, a distinction to which I will turn in section 3.2. Honneth does not seem to make this kind of distinction: standardized forms of recognition such as being evaluated on a scale of 1-5, being awarded a diploma, or receiving a carefully made positive critique of one's exhibition would be examples of social esteem for Honneth, but for Girard ot the two first forms of recognition, being standardized, are not examples of admiration. Although her references include Honneth's work, Girardot's theory of recognition is Arendtian in its basic concepts. This paper is concerned with Girardot's own theory and its interesting implications. The Honnethian threefold division and Girardot's twofold division of recognition help shed light on different questions. Honneth's theory is here used for comparison with Girardot's theory. ${ }^{5}$

The difference between Girardot's and Honneth's theories is noticeable in Girardot's usage of the term 'singularity' (singularité). The idea of singularity is related to Girardot's Arendtian understanding of human 
beings and the human condition of natality, the possibility of something totally new in the world with each new human being that enters the speech community (Arendt 1998, 8-9). Girardot's term singularity refers to this, to each person's uniqueness. ${ }^{6}$ It is this singularity which is overlooked when recognition becomes standardized. How could each and everyone's singularity, their uniqueness, be appreciated in concrete situations in the sphere of social esteem? Do we not need some common criteria in order for us to be able to appreciate anything at all? The problem is linked to differences in Honneth and Girardot's theoretical background.

Girardot's critique is targeted at the practice and demand of measuring human action. This restricts the scope of examination for her part to the domain of action that she calls the domain of 'initiatives, of beginning' (Girardot 2011, 171), i.e. the birth of something new that is not yet recognized as important or significant. Although she does not say this explicitly, this seems to be linked more to the category of admiration than to that of respect. Girardot sees the ideology of merit as a threat to Arendtian plurality and natality, the multi-voicedness of human co-existence and the introduction of something unexpectedly new among human beings. In the context of Arendt's work it is then fitting - and to be precise, necessary - to conceive of a form of recognition that combines both the singular and general: an action is always deeply personal and issues from an unprecedented source that springs from the human condition of natality (Arendt 1998, 179), but this uniqueness and singularity can only appear within human communality, in the public sphere. As for the commonness needed for the appreciation of merit (needed even when appreciating something unique such as the singularity of each person), Girardot would reject the rigid standards and pseudo-objectivity (further described in section 3.2) and resort to the Arendtian concept of judgment: the criteria would be negotiated through reflective judgment, taking the particular case as the starting point.

This paper cannot attempt a full comparison between Honneth and Girardot's work, but it seems evident that the two emphasize different aspects of recognizing remarkable deeds and people. In his later work, Honneth conceptualized the third sphere of recognition slightly differently: he writes of 'the "achievement principle" as a selective embodiment of social esteem' (Fraser \& Honneth 2003, 147). The achievement principle concerns acts whose merit lies in their contribution to the society. Honneth is aware of the problems related to the achievement principle and refers to it as a 'double-edged source of legitimacy' (Fraser \& Honneth 2003, 147). His analysis recalls in some respects Girardot's critique of the ideology of merit (Fraser \& Honneth 2003, 148-149). Nonetheless, the problems that Honneth and Girardot discuss are not the same. For Honneth a problem caused by 
the achievement principle is for instance the non-recognition of housewives' work. This is linked to bias and the implicit values of the society. Girardot's problematic is linked to the denial of the category of action by the ideology of merit. Girardot is interested in the personal input in a remarkable action that goes unrecognized because it cannot be measured or does not fall into standardized categories. The possibility of recognizing admirable actions also becomes threatened: the denial of action takes meaning away from such ideas as doing something for 'love of the world' (to paraphrase Hannah Arendt; see Young-Bruehl 2006, 79). Instead people are taken to act solely to be rewarded for it.

A final remark on the differences between Honneth and Girardot: for Girardot a pathological situation is one in which critical reflection ends and decisions are instead made based on standardized and unchangeable measurement. In such a situation, Girardot claims, actual recognition cannot be given. If recognition is not given even though from some point of view it ought to be given, this as such does not necessarily create a pathology of recognition but is something that follows from the nature of recognition as a freely issued gift; that recognition between people cannot be forced or demanded as a due. It seems to me that such a situation where recognition is not given though it ought to be given can also be pathological. Girardot's stance on the issue remains unclear. It seems to me she would agree that such a situation can be, at the least, tragic and wrong. However, in La Société du mérite Girardot focuses on cases where the core of the problem is not the lack of recognition between people, but an ideology and procedures that distort our concept of recognition; and this problematic creates situations where no recognition can be given between people. In the next sections I will demonstrate why Girardot takes this stance.

\section{Merit and Pathologies of Recognition}

\subsection{Merit and Recognition}

In Girardot's account, in contemporary society there is something wrong in the relations between merit and recognition (especially recognition of remarkable actions, that is, admiration in Girardot's terms). ${ }^{7}$ The problem is that measuring merit is often understood as the main instrument of granting recognition. I interpret Girardot to be referring to a wide variety of things when she speaks of measuring: for instance, measuring an individual's input in a collective enterprise; measuring the results or the efficiency of her work; or measuring her abilities or her more abstract 'potential' through testing. In Girardot's interpretation measuring aims at measuring people's utility. A 
personal input that would express the personality and life experience of the measured person doesn't count, because how it reflects in the work cannot be counted (Girardot 2011, 106-107). Through a mechanical measuring process, a person can only get their due, possibly a fair share, but not recognition. ${ }^{8}$ In my interpretation this difficulty in attaining recognition seems to create a pathology of recognition.

\subsection{Merit as Objectified Recognition}

Girardot conceptualizes human life in terms of conflict, recognition and coexistence. Human beings become who they are in conflictual relationships with other human beings who can either grant them and their actions recognition or deny it. This means recognition is simultaneously something we need and something we might not get. This intrinsic feature of recognition is addressed by the ideology of merit in a problematic way. According to Girardot merit is now seen as objective or 'objectified' recognition. ${ }^{9}$ This expression refers to many things, the first being that the procedures of granting merit aim at being as objective as possible. This is in itself a good goal but it is realized in a problematic way. Maintaining that recognition has to be measured in this pseudo-objective fashion has several harmful consequences for our understanding of recognition.

Recognition has to be assessed objectively to ensure it is legitimate (Girardot 2011, 133), or, in other words, recognition needs to be earned, merited. This is self-evident. However, when trying to realize this goal, the conception of objectivity can become distorted. According to Girardot it seems that we want to be recognized through a supposedly fully objective procedure. She writes that with this kind of procedure we are 'posited (posés) as a thing in itself, independently of all social rapport, of all rapport to our peers' (Girardot 2011, 141). My interpretation is that this is done to ensure that a person is not judged for the bad deeds of their predecessors or for the person's relations to any other people. The wish seems to be that a person could be evaluated without any reference to others (Girardot 2011, ibid.). However, also the beneficial effects of certain kinds of family backgrounds are left out of the picture, and such effects can give some persons considerable advantage. ${ }^{10}$ According to Girardot, ultimately the ideal of objectivity turns into a fantastical idea of valuing a person independently of all value judgments (Girardot 2011, ibid). This is impossible. To clarify this claim Girardot uses wages as a counter-example for the idea of 'selfdetermining' value: wages do not reflect an intrinsic value but a certain state of representations of value and of social forces at the present moment ${ }^{11}$ (Girardot 2011, 136). Correspondingly people and their skills are always 
appreciated in a certain environment and community of value. These values cannot be accepted as indelible without any scrutiny or possibility of reassessment even though this is what the search for objective recognition aims to do. Also, such a strict procedure cannot recognize new kinds of merits.

The sort of objectivity that is sought after in measuring procedures seems quite curious. Why would people want to be evaluated in this way? The answer to this, according to Girardot, lies in human insecurities and the precariousness of recognition. The ideology of merit works as a psychological bulwark against feelings of injustice. Once human beings dedicate themselves to something, the rejection by others feels devastating (Girardot 2011, 46-47).

This idea of 'objective' recognition is linked, according to Girardot, to a conception of justice as the reward or remuneration (récompense) of one's efforts. If rewarding efforts is considered justice, Girardot points out, it is then crucial that the measuring of efforts is done as exactly and precisely as possible (Girardot 2011, 27, 130). It is not hard to understand why conceptualizing recognition in this way, via merit, is so appealing. That someone should be esteemed for no real reason seems unjust. In that situation they do not deserve the esteem they are given. This is why it is often thought that some proof needs to be provided to justify the esteem. This happens nowadays preferably in the form of standardisable merit: by having qualifications and by being evaluated objectively.

\subsection{Problems Relating to Objectified Recognition}

There are several problems related to the new, supposedly objective conception of merit and the idea that recognition could be captured best by this conceptualization. I will go through them in the next two subsections. The first problem lies in 1) the attempt to evaluate efforts in a mechanical way, most often simply by quantitative means. For instance, bibliometrics such as journal rankings are thought to be objective as they enable nonexperts to evaluate the quality of expert work without any substantial knowledge of the issue (Rini 2013, 130). A very bad article may be mentioned in several other articles for its low quality - yet this means the article gets many references, which is considered a merit by simplifying quantitative measuring. As a consequence the bad article will be interpreted to be meritorious by non-expert evaluators who only consider the numbers.

Interestingly enough, Adriana Rini points out that bad bibliometrics are even capable of reinforcing existing biases instead of enhancing the objectivity of evaluation: Rini has studied the effect of such quantitative 
measurement procedures in hiring at philosophy departments in New Zealand universities. According to her findings the supposedly objective procedures have led to the exclusion of women from philosophy departments and professional philosophy (Rini 2013, 130-131).

Objectification of the concept of merit also seems to have another, rather concrete meaning. The second problem is that 2) what counts as merit is in constant danger of becoming an 'object', that is, reified. With standardization of the processes of granting merit only certain, already established forms of excellence can be recognized as merits.

Referring to one of the central concepts of Arendt's political theory, Girardot writes that human life is manifested in a plurality of human beings (Girardot 2011, 133, 145). What a person says or does will always be interpreted by the plurality of other people and this means the meaning of an action is never fully settled (Girardot 2011, 131-132, 145). This plurality and this nature of action (in Arendt's sense) cause human co-existence to be emotionally risky. Human beings act in the world and by their actions they become and manifest who they are (Girardot 2011, 106; 171-173). However, they might not be properly understood or accepted by others: the meaning of an action can never be conclusively decided, because it can always be interpreted and reinterpreted by the open-ended plurality of human beings. The ideology of merit then tries to offer both psychological comfort and a procedural, standardized guarantee of fair treatment. It grants, if not automatic recognition, then at least an automatic remuneration for one's efforts, one that cannot be denied. This creates the third problem relating to the new way of conceptualizing merit and the search for objective recognition: 3) a confusion of recognition and remuneration. The concept of recognition moves away from being something like a gift, freely issued and symbolic. Instead, it becomes something that one expects to receive, something that is due to one. Richard Münch has made a point reminiscent of Girardot's recognition/remuneration distinction, calling it 'the intermeshing of payment and respect in the capitalist economic sphere' (Fraser \& Honneth 2003, 141). Actual recognition given by others is far less assured. The remuneration does not feel quite the same as actual recognition, for it not only changes the hoped-for recognition into a concrete remuneration but also changes what is done: a singular action is turned into a standardized performance. The ideology of merit offers a substitute for recognition that is not as scary and precarious; the psychic bulwark mentioned earlier in this section. Unfortunately, the human need for actual recognition, for the recognition of both the action and the subject's singularity rather than mere automatic remuneration, does not vanish with this move. 
The fourth problem is that 4) the supposedly objective recognition that is due to anyone who has followed procedure accordingly makes acting (in Arendt's sense) in the world seem superfluous - incomprehensible and unnecessary. It seems to me that action will always take place: people still do charity work, act in theatres and write poems without external incentives such as money. However, action cannot be met according to its actual nature and be publicly appreciated as meaningful and important human activity. This is why hobbies are increasingly formulated as activities that enhance individuals' ability to recover from work and relieve stress instead of as action, activities that are done with and for other people and in order to make manifest to others who we are. In a similar vein, the discourse on art's ability to improve well-being is turning art into an instrument of governmental health policy and ties it to measurable utility. What is lost in the process is the ability to understand, conceptualize and grant recognition to other dimensions of art that are much more intrinsic to it than utility. ${ }^{12}$

\subsection{Measuring: Subject Limited to Factuality}

The testing and measurement of efforts and merits is done to improve the fairness of merit-based divisions of possibilities or wealth. For Girardot this is problematic not simply because of the consequent denial of action. This brings us to the fifth problem relating to attempts to measure merit in a pseudo-objective manner: 5) in testing and measuring, the subject is limited to a factual description of themselves. Measuring merit means 'hijacking,' as Girardot puts it, 'the aspiration for recognition' and bringing it to 'a domain where it does not belong: the domain of the facts' (Girardot 2011, 130-132). What Girardot means by this is a manoeuvre in which human beings are taken to be fully definable by and reducible to factual information. In this subsection I will first address some questions relating to this claim. Then I will tie them to the problem of limiting the subject to a factual description of themselves.

Firstly, one might ask, isn't recognition almost always tied to facts? Recognition as praise given to a skill or personal trait etc. can be tied to facts, for instance, to what has been done. The point is, it cannot be tied to facts once and for all, for our interpretations of such facts are susceptible to change: historical changes, changes to what is valued, etc. Someone can for instance kill whales excellently. Still, for many people, the excellence of the act is not considered praiseworthy but instead the excellent whale killer is thought to be cruel. Then again, for some, whose daily survival might depend on whale meat, the excellence is clear. Similarly, a work of art can be overlooked by contemporary audiences and experts but recognized as remarkable after 
decades or even centuries. This has been seen possibly most famously in the case of Vincent van Gogh; also in the scientific world new ways of thinking are not always easily accepted as the slow transition to Einstein's relativist worldview shows. Also, people can change, for instance, by learning new skills or adopting new moral principles or life goals which make them treat other people with more respect. This kind of personal change can affect our judgment of them. According to Girardot, the allegedly objective measurement serves to get rid of the essential plurality and open-endedness of human judgment and the inevitable 'multi-voicedness' of human (co)existence (Girardot 2011, 132). The aim is to define in fully 'objective', exact and most often quantitative means phenomena that cannot, by their nature, be pinned down conclusively (ibid.).

This, then, raises a second point: Girardot does not deny the need to assess ${ }^{13}$ recognition but points out that it needs to be done with respect to what recognition itself is: recognition does not rise from 'quantifiable measurement,' but instead is 'symbolic' (Girardot 2011, 133). This is why the result of assessing recognition 'is not a number to be counted, but a symbol that indicates greatness' (ibid). Girardot refers constantly to Arendt's account of judgment, and opposes judgment with evaluation. So, recognition ought to be assessed or judged but not evaluated. I cannot elaborate on Girardot's distinction here but my interpretation of how evaluation and judgment relate to the topic at hand is that legitimating recognition cannot be a strict mechanical procedure (evaluation) but a negotiation among human beings on what they value and why (judgment; see also Girardot 2011, 143). The differentiation between action and labor is clear here. Action is something that can be recognized. However, evaluation sets action aside and uses instead the quantifiable and standardisable merits as the basis for 'recognition'. Recognition becomes the aforementioned mechanical procedure and reduces action to a mere performance. Evaluation brings labor to the core of recognition and distorts it: labor as the center of recognition means that only the efficiency of activity can be recognized (Girardot 2011, 113). This, then, is not actual recognition. According to Girardot, 'measuring evaluates what is done,' whereas recognition concerns who acts, the singularity of the person that is manifested in action (Girardot 2011, 132). The power of action to change values and significations and create new ones is dismissed or neglected when evaluation attempts to grasp it. It is not able to identify genuine newness and originality even though what it attempts to reward can be something unique and unforeseen. ${ }^{14}$

Counting merits is not a 'symbol that indicates greatness' and, as a consequence, the given recognition is made banal in the process. It would seem that anyone with similar achievements and merits could be granted 
the same recognition, which turns remarkable achievement conceptually into a standardized performance that is linked to measurable and quantifiable utility. Action is reconceptualised as a subfield of labor: it is linked to the process of life and survival and its efficiency at maintaining life and maintaining its own existence becomes its key feature even though this is not what action is about. The point of, for instance, art is not survival, it is the creation of meaning, and in particular of new meanings - however, as we try to justify the public funding of art it seems that this apparent 'uselessness' of art seems to prove that as it is not necessary (which is obviously true, but it does not mean art is insignificant), that it is something extra which one should only be allowed to enjoy if one can afford it.

With these remarks, we can return to the original problem presented at the beginning of this subsection: how measuring merit limits the subject to a factual description of themselves. Measuring merit is, according to Girardot, mentally and socially disastrous (Girardot 2011, 130). Measuring is thought to bring forth objective knowledge of the measured people or activities. Via merit, recognition is assimilated into the facticity of measurement. This creates a confusion of recognition and mistaken objectivity: by claiming to separate recognition from all subjective contexts, measuring procedures paralyse human beings to their current state. Claiming to have found objective facts about the measured people can actually mean causing damage to them. This is because facts about human beings are not like facts about things. Human existence and activity cannot be defined by or reduced to objective measures, because they are fundamentally invested with meaning and always producing new meaning. There is always something that escapes attempts at controlling and defining (Girardot 130-131).

Quantitative measuring of unmeasurable things is only a part of the problem. Girardot is referring to concrete testing situations that aim to evaluate for instance the suitability of a person for a job. The method of the evaluation, whether it is an IQ-test, quantitative measuring or an interview is not important. The problem lies in the attempt to pin down for instance personality traits as definitive, whereas in reality, as Girardot puts it, we are not owners of our traits and abilities but merely their depositories (Girardot 2011, 139). Even our merits, such as abilities, are susceptible to change. In the working world the problem can manifest itself as an inability to accept the possibility of change; possibly the employers' reluctance to hire young women could be interpreted as such: a pregnancy and consequent motherhood are seen as negative changes in the employee that merely cause expenses for the employer. In hiring, on the other hand, 'potential ability' is becoming the most sought after trait in an applicant. Richard Sennett has 
plunged into the difficulties in defining, let alone locating, such potential ability and concludes that testing and making conclusions about someone's potential is a 'damaging measure of talent' (Sennett 2006). It seems there is also a grave difficulty in accepting the possibility of a positive change, learning and development in an employee. This is something that might take time and might not happen at all in the end. Due to this uncertainty of the outcome, believing in an employee's potential ability becomes a risk the employers do not wish to take. In light of this, the 'potential ability' sought after in job interviews is starting to look rather curious: it is something that, in order to be perceived as potential, needs to present itself as already actual.

Based on Girardot's account, I argue that the damage done to the evaluated in meritocratic assessments can be conceptualized as the stereotype threat phenomenon. Once it is indicated that often girls do not do as well as boys in math tests, girls taking such a test will more likely underachieve. Numerous studies have shown that human beings' ability to succeed can easily be shaken when the testers remind them, even in indirect and implicit ways, of the negative stereotypes associated with the categories under which they are classified (for instance stereotypes relating to gender, ethnicity, and age: see e.g. Spencer, Steele \& Quinn 1999; Stone et al 1999). If the stereotype threat is not taken into consideration in testing situations, the new results will more likely be interpreted as giving further evidence of the lesser abilities of the persons belonging to a group that is already generally seen to be less able. Facts concerning human beings as individuals are not objective in the sense that they could be measured at any moment in any conditions and circumstances. The measuring as such is a social relation with social conditions. ${ }^{15}$ Thus the measurement results do not reflect any unchanging objective identities of the tested persons. Identifying a person with their measured performances or results risks reifying (objectifying) them (Girardot 2011, 132). The demand to grant opportunities on the basis of measured merits reduces persons to their performances and potentialities to actualities ${ }^{16}$ (Girardot 2011, 130-131).

With human facts there is always a possibility of a global revaluation of all standards. This openness in human action can manifest itself as artistic and scientific innovations, learning, and personal transformation. This fundamental openness can be illuminated by the simple example of junior sports: young athletes' current success is often taken to indicate future success in sports in general. This has been shown to be a false supposition: the differences in maturation make predicting future success very difficult (Pearson, Naughton \& Torode 2006). The problem in merit-measuring procedures is that the fundamental openness and uniqueness of human action is not, and cannot be, taken into consideration. 


\section{Conclusion}

The ideology of merit seeks to secure everyone's bit of recognition by standardizing and objectifying it. According to Girardot, the reason for this is obvious. Human beings need and yearn for recognition, for they are and cannot be otherwise but 'within' the conflictual relations of recognition.

However, this move brings several problems along with it. Firstly, as quantifiable methods may be simpler to use than a complex examination of the subject matter, objective knowledge (of merits, of efforts) is thought to be attained most conveniently by simplifying quantitative methods. This means unmeasurable things are being measured and what cannot be measured doesn't seem to exist at all. Secondly the conception of merit constantly faces the threat of becoming reified: standard procedures can only recognize certain types of merit. Thirdly, this automatic process that only recognizes certain merits offers a fixed remuneration for it. This remuneration is not the same as authentic recognition of the singularity of the action or the person. People might demand something of the kind but once such a process of automated 'recognition' is set, the recognitionbecome-remuneration becomes inflated and loses its meaning as a way to recognize something remarkable. Fourth: action in Hannah Arendt's sense, that is, activities that are done simply because we live among other people, becomes incomprehensible and seems unnecessary: it cannot be met in the public sphere as it is, but instead its public funding faces difficulties. Action's existence needs to be justified by external beneficial effects. The existence of these effects can be hard to verify. This also threatens critical action: for instance the creation of theatrical pieces that do not 'benefit' the spectators but make them feel inadequate, guilty or express their wishes to overthrow the government become hard to justify. The fifth problem is that by testing and verifying one's merits, people are condemned to their current state and their possibilities are limited to actualities.

These five problematic aspects in the attempt to objectively measure merit with standardized criteria make for a pathology of recognition: it becomes impossible to attain actual recognition within these conditions. This is because actual recognition means having to deal with the fact that recognition might not be given: it is freely issued and may arrive centuries too late. What is offered instead is a standardized remuneration for certain merits and constant evaluation that can only further standardize our conception of human action; the possibility of change and genuine newness start to appear impossible.

The nature of actual recognition as freely issued and spontaneous is a problem in our society, for very often the appreciation of certain work is 
used to justify the salary of the people doing that work. Or, a lack of merits (for instance a lack of abilities that are recognized as useful in our society) is used to justify the exclusion of some persons from working life and all the benefits that follow. For the unemployed in some countries this means starving. Recognition of certain kinds of work as valuable and others as not is always tied to values and as such is subject to historical change. This is why I argue that one's livelihood should not be dependent upon the recognition of one's input in the society. Recognition should stay on another level than these questions for it is not possible to measure the worth of someone's actions objectively - even if it were, it still bears no implication for the worth of the person and their rights to a decent life. In practice this would mean a basic income that is paid to everyone regardless of ability to earn (merit) a living. Girardot also argues for such a model of social security (Girardot 2011, 203).

Finally, Girardot's twofold division of recognition and the inclusion of singularity in both of these categories offer an interesting addition to Honneth's theory of recognition. The manifestation of one's singularity through action in the public sphere is, I think, at the core of the need for recognition: to be recognized as who one is, through being distinct from everyone else in one's singularity and, simultaneously, to be considered admirable; this seems to be central to the power and meaning of recognition for human beings and their lives.

Heidi Elmgren (heidi.elmgren@jyu.fi) is a PhD student at the University of Jyväskylä. In her work she studies critically the idea of meritocracy.

\section{Bibliography}

Arendt, H. (1998 [1958]) The Human Condition, $2^{\text {nd }}$ ed., Chicago: University of Chicago Press

Arendt, H. (1992) Lectures on Kant's Political Philosophy Chicago: University of Chicago Press

Arendt, H. (1986) The Origins of Totalitarianism London: André Deutsch

Arendt, H. (1971) 'Thinking and Moral Considerations' Social Research 38:3, New York: New School for Social Research, pp. 417-446

Benhabib, S. (1988) 'Judgment and the Moral Foundations of Politics in Arendt's Thought' Political Theory vol. 16, no.1, pp. 29-51 
Birmingham, P. (2006) Hannah Arendt and Human Rights. The predicament of Common Responsibility Bloomington \& Indianapolis: Indiana University Press

Fraser, N. \& Honneth, A. (2003) Redistribution or Recognition? A PoliticalPhilosophical Exchange London: Verso Publishing

Friedman, M. (2013) 'Women in Philosophy: Why Should We Care?' in K. Hutchinson\& F. Jenkins (eds.) Women in philosophy - What needs to change? Oxford \& New York: Oxford University Press

Girardot, D. (2011) La Société du mérite - Ideologie méritocratique E violence néoliberale Lormont: Bord de l'Eau

Graeber, D. (2008) 'Give it Away' The Anarchist Library Available online, accessed 11/14/2014: http://theanarchistlibrary.org/library/david-graebergive-it-away

Heinämaa, S. (forthcoming) 'Chapter 6: Future and Others' in R. M. Schott (ed.) Birth, Death and the Feminine: Essays in the Philosophy of Embodiment Bloomington: Indiana University Press

Honneth, A. (1995) The Struggle for Recognition - The Moral Grammar of Social Conflicts (trans. J Anderson) Cambridge, MA: MIT Press

Jenkins, F. (2013) 'Singing the Post-Discrimination Blues: Notes for a Critique of Academic Meritocracy' in K. Hutchinson \& F. Jenkins (eds.) Women in philosophy - What needs to change? Oxford \& New York: Oxford University Press

Lareau, A. (2003) Unequal Childhoods: Class, Race, and Family Life Berkeley: University of California Press

Mill, J. S. (2001 [1863]) Utilitarianism Kitchener, Ontario: Batoche Books, Available online, accessed 04/24/2014:

http://socserv.mcmaster.ca/econ/ugcm/31l3/mill/utilitarianism.pdf

Murphy, E. \& Oesch, D. (2015) 'The Feminization of Occupations and Change in Wages: A Panel Analysis of Britain, Germany and Switzerland' SOEP paper No. 731 Available online:

http://papers.ssrn.com/sol3/papers.cfm?abstract_id=2564612\#\# 
Pearson D. T., Naughton G. A., \& Torode, M. (2006) 'Predictability of Physiological Testing and the Role of Maturation in Talent Identification for Adolescent Team Sports' Journal of Science and Medicine in Sport, vol. 9 iss. 4, pp. 277-287. Available online, accessed 05/10/2014:

http://www.fisioex.ufpr.br/resources/BE711/BE711--Pearson-JSMS-

2006.pdf

Rini, A. (2013) 'Models and Values: Why Did New Zealand Philosophy Departments Stop Hiring Women Philosophers?' in K. Hutchinson \& F. Jenkins (eds.) Women in philosophy - What needs to change? Oxford \& New York: Oxford University Press

Rosanvallon, P. (2013) The Society of Equals Cambridge \& London: Harvard University Press

Sennett, R. (2006) The Culture of the New Capitalism New Haven: Yale University Press

Spencer, S. J., Steele, C. M., \& Quinn, D. M. (1999) 'Stereotype Threat and Women's Math Performance' Journal of Experimental Social Psychology vol. 35, pp. 4-28 Available online, accessed 06/14/2015:

http://www.leedsmet.ac.uk/carnegie/learning_resources/LAW_PGCHE/Ste eleandQuinnStereotypeThreat.pdf

Stone, J., Sjomeling, M., Lynch, C. I., \& Darley, J. M. (1999) ‘Stereotype Threat Effects on Black and White Athletic Performance' Journal of Personality and Social Psychology, vol. 77 no. 6, pp. 1213-1227. Available online, accessed 06/14/2015: http://www.u.arizona.edu/ jeffs/golf1.pdf

Wortham, S. (2010) Derrida Dictionary London \& New York: Continuum

Young-Bruehl, E. (2006) Why Arendt Matters New Haven \& London: Yale University Press

\section{Endnotes}

${ }^{1}$ I would like to thank the following people for their useful comments: Sara Heinämaa, Hans Arentshorst, Joonas Pennanen, Arto Laitinen, Arvi Särkelä and Onni Hirvonen.

${ }^{2}$ Dominique Girardot is a contemporary French researcher and teacher of 
philosophy. She is a member of the French group of intellectuals M.A.U.S.S. "Mouvement anti-utilitariste dans les Sciences Sociales" founded by philosopher Alain Caillé. She has published one book and several articles in French on meritocracy but is still relatively little known outside of France. Her book La Société du mérite - Idéologie méritocratique et violence néolibérale was published in 2011. For more information on M.A.U.S.S., its connection to Marcel Mauss and its other leading ideas see Graeber 2008.

${ }^{3}$ In Girardot's theory, the ideology of merit is closely linked to other influential ideologies of our times. For instance, the emphasis on personal responsibility present also within the ideology of merit is linked to the neoliberal agent, homo oeconomicus, the "self-made man".

${ }^{4}$ It should be noted that the English verbs "to merit" and "to deserve" both translate into French as "mériter".

${ }^{5}$ I would like to thank Joonas Pennanen for an illuminative conversation on this section which clarified for me the differences between Honneth's and Girardot's thought and made it possible for me to articulate them more clearly.

${ }^{6}$ It was suggested that I translate 'singularity' as 'particularity,' as the meaning of 'singularity' in this context is reminiscent of it. However, I have decided not to change the translation, as using the term 'singularity' in contexts that could suggest the use of the term 'particularity' seems to have become more common. This can be seen in the work of Pierre Rosanvallon (2013), but a more pertinent example in this case is Giorgio Agamben, who, while writing on Hannah Arendt, uses this term (1998). Also, in Hannah Arendt and Human Rights (2006) Peg Birmingham has chosen to use this term. In light of these remarks I find it best to translate 'singularité' with 'singularity'.

Singularity is a concept used by Jacques Derrida in a way that would not at first glance seem relevant here. Girardot does not refer to Derrida's work when writing of singularity, but Simon Wortham's analysis of Derrida's concept of singularity reminds one of Girardot's use of the term. Wortham lists Derrida's many uses of the term and concludes: 'the singular, then, is that which remains irreducible to any established concept, code, system or generality. Always more and less than an example, its particularity cannot ever be fully apprehended by way of "universal" categories or criteria.' I argue that Girardot speaks of the singularity in each person in a similar vein. 
${ }^{7}$ It is worth pointing out that the ideology of merit affects also another Honnethian form of recognition. Ideology of merit is often present in political slogans, such as in 2006 former French president Nicolas Sarkozy's 'tout se mérite, rien n'est acquis, rien n'est donné' ('everything is earned, nothing is certain (or, nothing can be taken for granted), nothing is given'). In addition to the detrimental effects on esteem, the ideology of merit has, according to Girardot, also the potential of corrupting our conception of rights. Rights are usually thought to be unconditional, something given to everyone unexceptionally, but the ideology of merit with the above mentioned rhetoric can bring them to the sphere of things that have to be deserved (See e.g. Girardot 2011, 203).

${ }^{8}$ Girardot argues that recognition cannot be demanded as "a due", for being able to attain recognition or give recognition to others demands renouncing any position of power. The others have to be faced as equals who can either grant one their recognition or not. This risk has to be taken to be able to gain actual recognition that is not forced or standardized or pretended. Girardot, seemingly paradoxically, does write that recognition is due to us. Yet it cannot be demanded as a due. Within Girardot's view of human life as co-existence and so on this seems reasonable, but still the claim that one should not demand recognition seems problematic. The ones who are in a position to give recognition are often in a position of power and the struggle for recognition, demanding recognition as a due, is an attempt to claim equality with the oppressor. This is something Girardot seems to be promoting when speaking of renouncing positions of power. Possibly Girardot's position could be defended by pointing out that a situation in which someone who is higher in the hierarchy gives recognition to someone lower in the hierarchy is not, according to Girardot, genuine recognition. Yet this whole way of conceptualizing the issue can be criticized for bringing the very real problem of non-recognition further away from reality.

9 I've translated the term in most cases as "objectified recognition" or "objective recognition" depending on the context since Girardot writes mostly about "objectivisation" and "objectivity". Alternative translation would be "commensuration" or "commensurable recognition", as an anonymous referee suggested, but the objectivized recognition is criticized in so many cases that this would not cover all of them.

${ }^{10}$ For instance, the effect of social class on children's lives has been studied extensively by Annette Lareau in her book Unequal Childhoods: class, race and family life (2003). 
${ }^{11}$ For instance in public discussion in Finland it is sometimes pointed out that women just 'happen' to work more often in fields where wages are lower. In reality the fact that the field is dominated by women is directly connected to the lower wages in that field due to gender devaluation (see e.g. Murphy \& Oesch 2015).

${ }^{12}$ See e.g. Eleonora Belfiore's work on instrumentalism in cultural policy.

${ }^{13}$ What Girardot writes is literally: 'la reconnaissance, pour être perçue comme légitime, doit être mesurée.'(emphasis added) I think here the more correct translation could be "assessed" rather than "measured" because the English word doesn't seem to have the same alternative meanings as the French one.

${ }^{14}$ Onni Hirvonen pointed out that a struggle for recognition might at the same time be a struggle to make certain acts count as a merit. This is true. What is criticized here is a procedure that leaves no room for this kind of reassessment of what counts as merit, that is, where there is no room for human judgment.

${ }^{15}$ For this illuminative formulation I owe thanks to Professor Sara Heinämaa.

${ }^{16}$ Again I thank Professor Sara Heinämaa for this turn of phrase. 